\title{
Biochemical Approach for Virulence Factors' Identification in Xanthomonas Oryzae Pv. Oryzae
}

\section{Sylvestre Gerbert Dossa $C^{1,2 *}$, Petr Karlovsky ${ }^{1}$ and Kerstin Wydra ${ }^{3}$}

${ }^{1}$ Molecular Phytopathology and Mycotoxin Research, University of Goettingen, Grisebachstr. 6 37077, Germany

${ }^{2}$ International Rice Research Institute, Division of Plant Breeding, Genetics and Biochemistry, DAPO Box 7777, Metro Manila, Philippines

${ }^{3}$ Erfurt University of Applied Sciences, Altonaer Str. 25, 99085 Erfurt, Germany

\begin{abstract}
Bacterial blight caused by Xanthomonas oryzae pv. oryzae (Xoo) leads to a substantial yield reduction of up to $50 \%$ in most rice-growing regions. Host plant resistance is an effective control method, and more than 30 resistance genes have been identified in rice genotypes. To understand the interaction of the pathogen in a susceptible reaction of the host plant, Xoo culture filtrate and treated culture filtrates were used to treat two rice genotypes using four strains Mai1, PXO88, Dak1 and Dak16. The study revealed that Xoo culture filtrate, heated culture filtrate and proteinase $\mathrm{K}$ treated culture filtrate induced typical bacterial blight symptoms on rice genotypes IRBB4 and FKR14 with a maximum lesion length of about $23.1 \mathrm{~cm}$ for culture filtrate. Heated culture filtrate phytotoxicity effects on both rice genotypes was with highest lesion length of about $6.9 \mathrm{~cm}$, while $13.4 \mathrm{~cm}$ was the maximum length induced by a proteinase $\mathrm{K}$ treated fraction. After ethyl acetate treatment of the culture filtrate, a considerable reduction of the phytotoxicity was observed. Therefore we suggest that a low molecular-weight toxin may be present in the ethyl acetate extract should not play a major role in Xoo virulence and speculate that EPS, Xylanase, polygalacturonase, proteinaceouse contribute to $X_{0 o}$ virulence.
\end{abstract}

Keywords: Xanthomonas oryzae pv. Oryzae; Culture filtrate; Phytotoxicity; Rice; Virulence

\section{Introduction}

Xanthomonas oryzae pv. oryzae (Xoo) causes an important rice disease called bacterial blight. Rice bacterial blight was first reported in 1884 in Fukuoka, Prefecture of Japan and is today one of the most important rice diseases in Asia and Africa, implying huge economic consequences. Bacterial blight is the economically most important rice disease in the tropics Mew, Mew et al. [1,2] yield losses associated with the disease are up to $50 \%$ of the total yield [3]. During infection Xoo produces virulence factors such extracellular polysaccharides (EPS), extracellular enzymes, iron chelating side rophores and effectors of type III secretion [4,5]. These virulence factors were identified using molecular approach. The virulence factors play an important role in successful establishment of Xoo in the host plant. EPS such as xanthan and lipopolysaccharides (LPS) produced by Xanthomonas genus are involved in disease development [6]. It is also known that a diffusible signal factor (DSF) is required for virulence in Xoo [4,7-9].

In pathogenic fungi, a secondary metabolite production is well studied and their role in plant infection and their toxicity to humans are well described. Among plant pathogenic bacteria such as Xanthomonas spp. toxin production is reported in X. albilineans which produces albicidin, known as virulence factor [10]. A non-ribosomal peptide synthetase-polykitide synthase (NRPS-PKS) enzyme related to syringomycin (SyrE) responsible for syringomycin phytotoxin in Pseudomonas syringae is found in $X$. axonopodis pv. citri, but its toxins production is not known $[11,12]$.

Erdman et al. [13] reported that Rhizobia strains induce chlorosis on young soybean leaves. The toxic compound was later purified from Bradyrhizobium elkanii, and called rhizobitoxine, its phtytotoxicity was demonstrated on new soybeans leaves [14]. Rhizobitoxine has been identified as enol-ether amino acid (2-amino-4-[2-amino-3hydroxypropoxy]-trans-3-butenoic acid), with a molecular weight of 190. Rhizobitoxine has been reported to be an important virulence factor in many human and animal pathogenic bacteria and is found in many plant pathogenic bacteria such as X. fastidiosa, Rhizobium leguminosarum and Erwinia carotovora [15,16]. In the Xoo genome, two apparent RTX toxins, rtxA and rtxC, were identified after genome sequencing of the Korean Xoo strain KACC10331[17], but to date the virulence role of the RTX toxins is not yet proved.

Many studies had identified Xoo virulence factors using the molecular approach while little is known of their biochemical properties. To better understand the Xoo interaction with its host plant, a biochemical approach is needed. Earlier studies revealed that Xoo may produce several toxins such as phenylacetic acid (PAA), trans-3-methylthio-acrylic acid (MTAA) and 3-methylthio-propionic acid, which can cause wilting and chlorosis on its host [18]. Xoo culture filtrate inhibited rice seed germination [19], but the phytotoxic compounds from Xoo and their role in pathogen virulence in the riceXoo-pathosystem is still not documented. Our study was conducted to identify virulence factors in Xoo through phytoxicity effects of four different treatments of culture filtrate.

\section{Materials and Methods}

To determine the phytotoxivity effects and identify virulence factors, experiments with liquid culture of the bacteria were conducted. Four Xoo strains (Mai1, PXO88, Dak1, and Dak16) were selected

*Corresponding author: Gerbert Sylvestre Codjo Dossa, Molecular Phytopathology and Mycotoxin Research, University of Goettingen, Grisebachstr.6 37077, Germany, Tel: +81-97-586-584; E-mail: c.dossa@irri.org

Received: March 10, 2014; Accepted March 29, 2014; Published April 07, 2014

Citation: Sylvestre Gerbert Dossa C, Karlovsky P, Wydra K (2014) Biochemical Approach for Virulence Factors' Identification in Xanthomonas Oryzae Pv. Oryzae. J Plant Pathol Microb 5: 222. doi:10.4172/2157-7471.1000222

Copyright: ( 2014 Sylvestre Gerbert Dossa C, et al. This is an open-access article distributed under the terms of the Creative Commons Attribution License, which permits unrestricted use, distribution, and reproduction in any medium, provided the original author and source are credited. 
according to their virulence and location of origin, Mail from West Africa (African race 3), PXO88 from Philippines (race 9) and Dak1, Dak16 from Tanzania (East Africa). Two rice genotypes (FKR 14 and IRBB4) were used. The rice plants were grown for 3 weeks in the greenhouse and transferred into growth chamber for one week before inoculation under $28^{\circ} \mathrm{C}$ temperature and $78 \%$ relative humidity on the fourth week after transplanting.

The strains were grown on solid modified Wakimoto's medium ( $0.05 \mathrm{~g}$ of $\mathrm{Fe}_{2} \mathrm{SO}_{4}, 0.82 \mathrm{~g}$ of $\mathrm{NA}_{2} \mathrm{PO}_{4}, 0.5 \mathrm{~g}$ of $\mathrm{Ca}\left(\mathrm{NO}_{3}\right)_{2} 4 \mathrm{H}_{2} \mathrm{O}, 5 \mathrm{~g}$ of peptone, $15 \mathrm{~g}$ of agar and $20 \mathrm{~g}$ of sucrose dissolved in 1 liter of distilled water) for $48 \mathrm{~h}$ and a single colony was used to inoculate $300 \mathrm{ml}$ modified Wakimoto's liquid medium and incubated on a shaker for three days at $28^{\circ} \mathrm{C}$ and $180 \mathrm{rpm}$. After incubation, the liquid culture was centrifuged at $4754 \times g$ for $10 \mathrm{~min}$ and the supernatant filtrated by passing it through a membrane filter with $0.45 \mu \mathrm{m}$ pore size. For the following experiments, the culture filtrate was divided into 4 fractions: culture filtrate, boiled culture filtrate, culture filtrate with proteinase $\mathrm{K}$ and ethyl acetate extraction.

\section{Culture filtrate experiment}

Four week-old rice plants of rice genotypes IRBB4 and FKR14 were inoculated, by cutting the leaf tips with a pair of scissors priory dipped in the culture filtrate as described by $[19,20]$.

\section{Boiled culture filtrate}

One fraction of the culture filtrate was heated at $80^{\circ} \mathrm{C}$ for $10 \mathrm{~min}$ in water bath to kill the bacteria if still present in the filtrated culture and to inactivate enzymes. The heated culture filtrate was cooled down before use to inoculate rice plants by the leaf clipping method as described above.

\section{Culture filtrate with addition of proteinase}

The third fraction of the filtrated culture was heated at $40^{\circ} \mathrm{C}$ for $20 \mathrm{~min}$ followed by addition of proteinase $\mathrm{K}(5 \mu \mathrm{g} / \mathrm{ml})$ and heated at $70^{\circ} \mathrm{C}$ for $10 \mathrm{~min}$. By addition of proteinase $\mathrm{K}$, protein is degraded in the culture filtrate; the heated and treated mixture was centrifuged at 4754 $\mathrm{x} g$ for $10 \mathrm{~min}$ and the supernatant transferred into a new tube and used to inoculate rice plants by leaf clipping.

\section{Ethyl acetate extraction}

A culture filtrate of $100 \mathrm{ml}$ volume was extracted with an equal volume of ethyl acetate. The aqueous phase (ethyl acetate phase) was concentrated using a rotary evaporator until $75 \%$ of ethyl acetate were evaporated. The $25 \%$ left of the aqueous phase were transferred into a $50 \mathrm{ml}$ falcon tube and evaporated using speed vacuum. The product obtained after evaporation was re suspended with $2 \mathrm{ml}$ of $100 \mathrm{mM}$ $\mathrm{NaCl}$ and used to treat the rice plant by leaf clipping as described above. The control was performed with non-inoculated modified Wakimoto's medium. The bacteria suspension with $10^{6} \mathrm{CFU} / \mathrm{ml}$ was used as positive control.

\section{Evaluation and analyses of phytotoxicity and symptoms on rice genotypes IRBB4 and FKR14}

For each experiment, phytotoxicity or disease development were assessed by measuring the phytotoxicity effect on leaves as symptom length and the leaf length. Plants were checked daily and the data from 14 and 21 days post treatment were used to build a graph with mean lesion length induced by each strain on rice genotypes IRBB4 and FKR14. For ethyl acetate extract, the lesion length induced by the control (medium) was subtracted from the lesion length induced by each strain to receive the effect of the ethyl acetate extract. The whole experiment was replicated three times and the mean values were used for statistical analysis.

Statistical analyses were performed with Statistica software version 7. General Linear Models (GLM) were run for pair wise comparison of culture filtrate treatment to others and for all treatments.

\section{Results}

\section{Virulence of Xanthomonas oryzae pv. oryzae strains from different origin on rice genotypes IRBB4 and FKR 14}

The lesion length induced on leaves varied from $3.6 \mathrm{~cm}$ to $26.7 \mathrm{~cm}$ for IRBB4 and from $14.7 \mathrm{~cm}$ to $26.7 \mathrm{~cm}$ for FKR14, with the maximum lesion length of $26.7 \mathrm{~cm}$ at 14 and $21 \mathrm{dpi}$ induced by the Asian strain PXO88. The West African strain Mail induced a lesion length of 14.7 $\mathrm{cm}$ on genotype FKR14, while the East African strains Dak1 and Dak16 reached medium values with 20 and $21.5 \mathrm{~cm}$ of maximum lesion length, respectively, on rice genotype FKR14 (Figure 1).

X. oryzae pv. oryzae strains Mai1, PXO88, Dak1 and Dak16, selected for the biochemical analyses of virulence factors were virulent on rice genotypes IRBB4 and FKR14. The highest virulence level was exhibited by the Asian strain PXO88. A difference was found on the virulence levels of PXO88 between genotypes IRBB4 and FKR14 at $14 \mathrm{dpi}$, and at $21 \mathrm{dpi}$, the virulence level was nearly the same on both genotypes with $26.7 \mathrm{~cm}$ of lesion length. The West African strain Mai1 did not show a high virulence level at $14 \mathrm{dpi}$ and revealed to be the least virulent strain. All the strains showed a virulence progression on the rice genotypes except strain PXO88 which was highly virulent already after $14 \mathrm{dpi}$, infecting the whole leaf length of FKR14 after $14 \mathrm{dpi}$. The East African strains Dak1 and Dak16 were more virulent than the West African strain (Mai1), (Figure 1).

\section{Phytotoxicity of culture filtrate}

X. oryzae pv. oryzae culture filtrate of strains Mai1, PXO88, Dak1

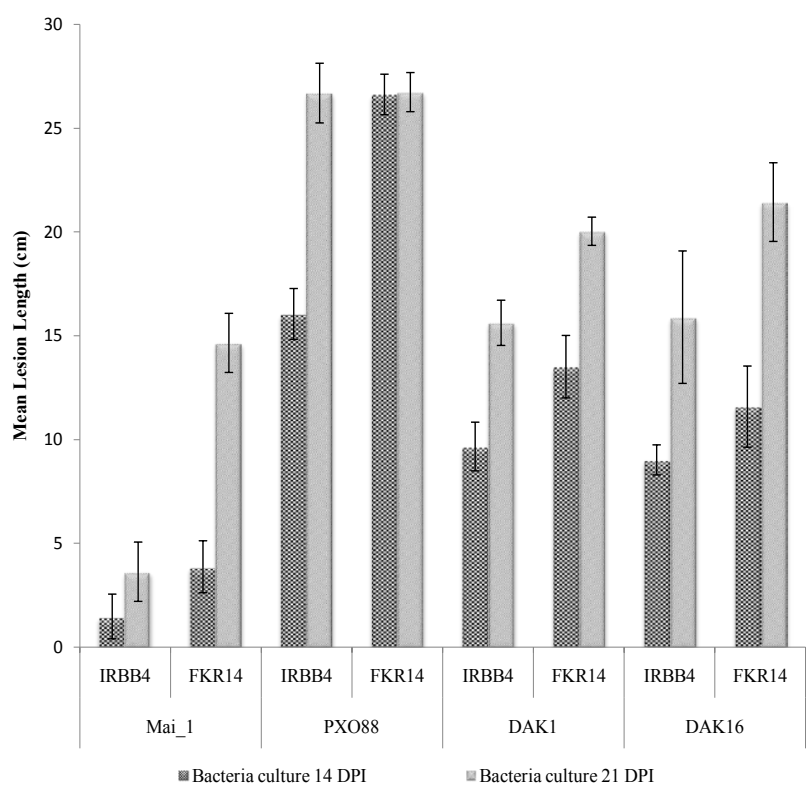

Figure 1: Virulence of $X$. oryzaepv. oryzae strains Mai1, PXO88, Dak1 and Dak16 expressed in mean lesion length [cm] on rice genotypes IRBB4 and FKR14 at 14 and $21 \mathrm{dpi}$. 


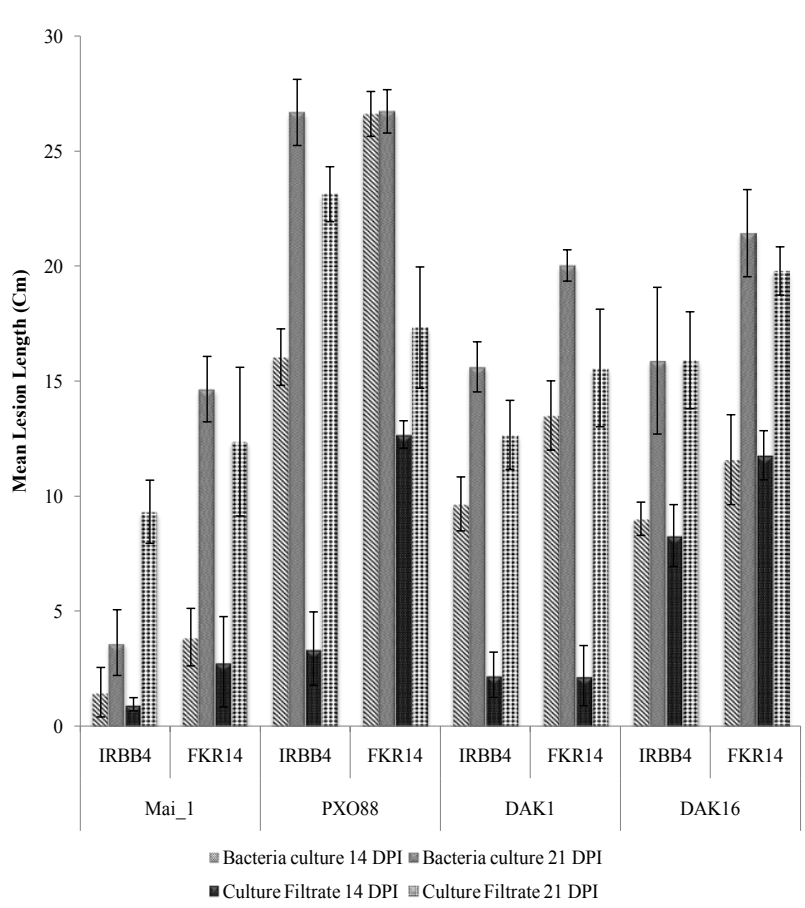

Figure 2: Comparison of $X$. oryzaepv. oryzae strains Mai1, PXO88, Dak1 and Dak16 culture effects to culture filtrate effects on genotypes IRBB4 and FKR14, measured in lesion length $[\mathrm{cm}]$ at 14 and $21 \mathrm{dpi}$.

and Dak16 induced phytotoxicity effects 14 and 21 days after leaf clipping treatment on both rice genotypes IRBB4 and FKR14. The phytotoxicity effects of Xoo culture filtrates on both genotypes in comparison to bacteria culture effects are presented as lesion length on leaves (Figure 2). Generally, lesion lengths at 14 dpi were lower in treatment with culture filtrate than in treatments with bacteria culture, with exception of strain Dak16, where lesion lengths from culture filtrate were similar to those from bacteria culture already at this time point. At $14 \mathrm{dpi}$ the phytotoxicity effect of culture filtrate varied from $0.95 \mathrm{~cm}$ to $12.7 \mathrm{~cm}$ lesion length with the highest lesion length induced by strain PXO88 on FKR14. The phytotoxicity effects scored at $21 \mathrm{dpi}$ showed a variation from $9.3 \mathrm{~cm}$ to $23.1 \mathrm{~cm}$ induced by strains Mail and PXO88, respectively, on rice genotype IRBB4. At 21 dpi lesions induced by culture filtrate had reached higher values and were comparable to the lesion induced by bacterial cultures in treatments with strain Dak16 on both rice genotypes, while the other strains values from culture filtrate treatment remained lower than the value from bacterial culture, except on the interaction between strain Mail and rice genotype IRBB4.

The statistical analysis of data derived from the 21 dpi measurement revealed significant differences between bacterial culture and culture filtrate treatments, strains and rice genotypes: bacteria culture induced higher lesion lengths than culture filtrate, strain PXO88 demonstrated higher effect on rice genotypes than the other strains, while rice genotype FKR14 was more susceptible than genotype IRBB4 (Table 1). Significant differences were also observed within treatments and strains, with culture filtrate of strain PXO88 inducing lower lesion length than its bacteria culture, and between treatments and rice genotype, with generally higher lesion lengths induced by culture filtrate on rice genotype FKR14 than on genotype IRBB4. The interaction of treatments, strains and rice genotypes was not significant.

\section{Phytotoxicity of heated culture filtrate}

The phytotoxicity effect of heated culture filtrates of Xoo strains Mai1, PXO88, Dak1 and Dak16 inoculated to rice genotypes IRBB4 and FKR14 was first observed one week after treatment. Lesions induced by heated culture filtrate were generally lower at $14 \mathrm{dpi}$ and in all treatments lower at $21 \mathrm{dpi}$ than values from non-heated culture filtrate (Figure 6). Lesion length from heated culture filtrate generally increased from 14 to $21 \mathrm{dpi}$ (Figure 3). The lesion length induced by heated culture filtrate varied from $1.8 \mathrm{~cm}$ to $5.1 \mathrm{~cm}$ with rice genotype IRBB4 and from $3.3 \mathrm{~cm}$ to $6.9 \mathrm{~cm}$ on FKR14 at 21 dpi (Figure 6).

Figure 6 and statistical results (Table 2) show significant differences between culture filtrate and heated culture filtrate treatments, with higher phytotoxicity effect of culture filtrate compared to heated culture filtrate on both rice genotypes. Significant differences were also observed between strains and rice genotypes, with strains PXO88 and Dak1 inducing the highest phytotoxicity effect on both rice genotypes, while strain Mail showed a lower lesion length on rice genotype IRBB4. Significant interactions with p-value 0.00 were also recorded between treatments and strains, with strain PXO88 culture filtrate showing a higher divergence on lesion length compared to heated culture filtrate on rice genotype IRBB4 than on genotype FKR14.

\section{Phytotoxicity of culture filtrate treated with proteinase $\mathrm{K}$}

Inoculation of culture filtrate of strains Mai1, PXO88, Dak1 and Dak16 treated with proteinase K to rice genotypes IRBB4 and FKR14 lead to a significant reduction in phytotoxicity lesion lengths compared to inoculation with untreated culture filtrate (Figure 6). Differences were higher at $21 \mathrm{dpi}$ than at $14 \mathrm{dpi}$. Only in the interaction strain

\begin{tabular}{|l|l|l|l|l|l|}
\hline & SS & DF & MS & F & P \\
\hline Treatments & 64.98 & 1 & 64.98 & 18.134 & $0.000169^{* * *}$ \\
\hline Strains & 1122.08 & 3 & 374.03 & 104.372 & $0.000000^{* * *}$ \\
\hline Rice Genotypes & 116.53 & 1 & 116.53 & 32.518 & $0.000003^{* * *}$ \\
\hline Treatments x Strains & 112.22 & 3 & 37.41 & 10.438 & $0.000061^{* * *}$ \\
\hline Treatments x Rice Genotypes & 53.57 & 1 & 53.57 & 14.949 & $0.000509^{* * *}$ \\
\hline Strains x Rice Genotypes & 161.94 & 3 & 53.98 & 15.063 & $0.000003^{* * *}$ \\
\hline $\begin{array}{l}\text { Treatments x Strains x Rice } \\
\text { Genotypes }\end{array}$ & 22.55 & 3 & 7.52 & 2.097 & 0.120142 \\
\hline Error & 114.68 & & 32 & 3.58 & \\
\hline
\end{tabular}

Note:*** p-value highly significant at 0.01 ; SC: Sum of Square; DF: Degree of freedom, MS: Mean square; F: F of Fisher; p: probability

Table 1: Statistics of comparison of Xanthmonas oryzae pv. oryzae culture effects to culture filtrate effects at $21 \mathrm{dpi}$.

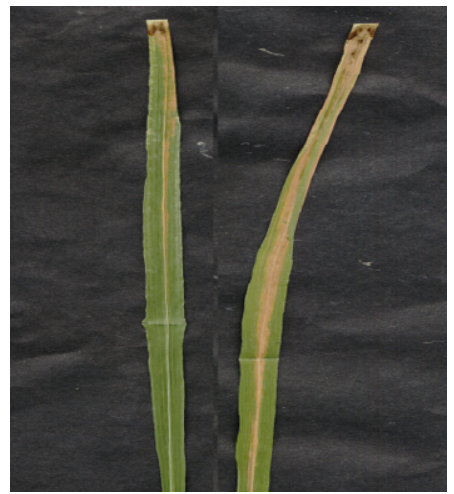

Figure 3: Heated culture filtrate induced lesion on rice genotypes IRBB4 and FKR14 at $21 \mathrm{dpi}$. 


\begin{tabular}{|l|l|l|l|l|l|}
\hline & SS & DF & MS & F & P \\
\hline Treatments & 1467.330 & 1 & 1467.330 & 306.030 & $0.000000^{\star * *}$ \\
\hline Strains & 170.705 & 3 & 56.902 & 11.868 & $0.000022^{* * *}$ \\
\hline Rice Genotypes & 36.453 & 1 & 36.453 & 7.603 & $0.009548^{* \star *}$ \\
\hline Treatments x Strains & 164.669 & 3 & 54.890 & 11.448 & $0.000029^{* * *}$ \\
\hline Treatments x Rice Genotypes & 6.564 & 1 & 6.564 & 1.369 & 0.250631 \\
\hline Strains x Rice Genotypes & 46.760 & 3 & 15.587 & 3.251 & $0.034465^{\star *}$ \\
\hline $\begin{array}{l}\text { Treatments x Strains x Rice } \\
\text { Genotypes }\end{array}$ & 63.189 & 3 & 21.063 & 4.393 & $0.010683^{\star *}$ \\
\hline Error & 153.431 & 32 & 4.795 & & \\
\hline
\end{tabular}

Note:*** p-value highly significant at $0.01 ;{ }^{* *}$-value significant at 0.05 ; SC: Sum of Square; DF: Degree of freedom, MS: Mean square; F: F of Fisher; p: probability

Table 2: Statistics of comparison of Xanthmonas oryzae pv. oryzae culture filtrate effects to heated culture filtrate effects at $21 \mathrm{dpi}$

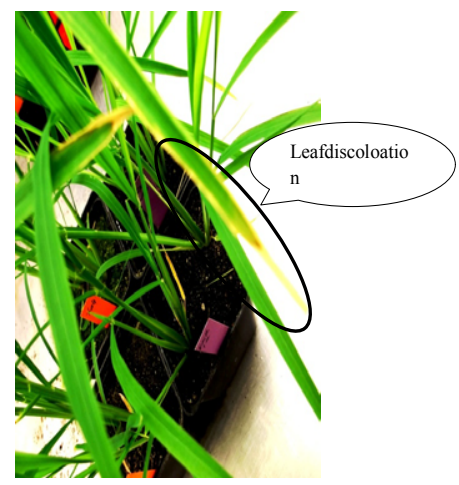

Figure 4: Leaf discoloration symptom induced by ethyl acetate extract on genotype FKR14 at 14 dpi.

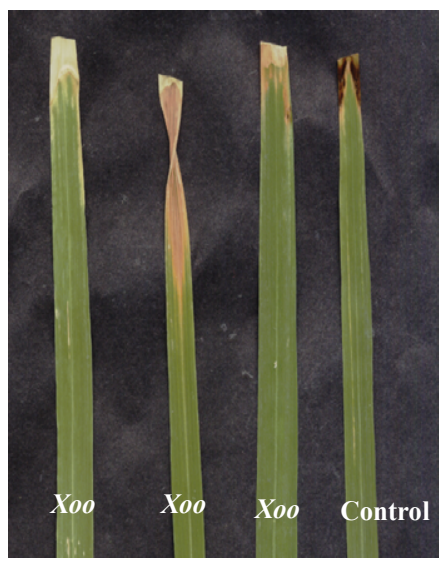

Figure 5: Effect of ethyl acetate extract from culture filtrate of $X$. oryzaepv. oryzae on leaves of rice genotype FKR14 at $21 \mathrm{dpi}^{(\mathrm{a})}$.

Dak1 on rice genotype FKR14, values from untreated and proteinase K treated culture filtrate were similar. At $14 \mathrm{dpi}$, inoculation with culture filtrate treated with proteinase $\mathrm{K}$ resulted in minimum and maximum lesion lengths of $0.6 \mathrm{~cm}$ and $1.7 \mathrm{~cm}$ induced by strain Dak1 on rice genotypes IRBB4 and FKR14, respectively. The phytotoxicity effect of proteinase $\mathrm{K}$ treated culture filtrate increased at $21 \mathrm{dpi}$, varying on rice genotype IRBB4 from $1.5 \mathrm{~cm}$ to $5.4 \mathrm{~cm}$ and on rice genotype FKR14 from $4.1 \mathrm{~cm}$ to $13.4 \mathrm{~cm}$. at $21 \mathrm{dpi}$, with maximum lesion lengths of 5.4 $\mathrm{cm}, 5.9 \mathrm{~cm}, 13.4 \mathrm{~cm}$ and $4.2 \mathrm{~cm}$, induced by treated culture filtrates of Xoo strains Mail, PXO88, Dak1 and Dak16 respectively.

The comparison between culture filtrate effects to culture filtrate treated with proteinase $\mathrm{K}$ effects (Figure 5) and the statistical analysis at $21 \mathrm{dpi}$ (Table 3 ) revealed significant differences $(\mathrm{p}=0.00)$ between culture filtrate and proteinase $\mathrm{K}$ treated culture filtrate, with a lower phytotoxicity effect induced by proteinase $\mathrm{K}$ treated culture filtrate than with untreated culture filtrate, while the strain Dak1 induced similar lesion lengths with both treatments on rice genotype FKR14 at $21 \mathrm{dpi}$.

Significant differences were observed between treatments and rice genotypes $(\mathrm{p}=0.03)$, where both treatments induced higher phytotoxicity effects on rice genotype FKR14 than genotype IRBB4 at 21 dpi. Only strain PXO88 culture filtrate induced higher lesion lengths on genotype IRBB4 than on genotype FKR14.

\section{Phytotoxicity of ethyl acetate extract from culture filtrate}

$X$. oryzae pv. oryzae ethyl acetate fraction fromculture filtrate was used to investigate a possible role of small molecules as virulence factors of Xoo. Inoculation of culture filtrate extracted with ethyl acetate by leaf clipping resulted in a highly to totally reduced phytotoxicity induction (Figure 6). Nevertheless the phytotoxicity effects of the ethyl acetate fraction after leaf clipping treatment varied from $0.6 \mathrm{~cm}$ to $3.4 \mathrm{~cm}$ and $1.9 \mathrm{~cm}$ to $3.99 \mathrm{~cm}$ on rice genotype IRBB4 and on FKR14, respectively, at $21 \mathrm{dpi}$. The phytotoxicity effects were first observed 3 days after treatment with leaf discoloration symptoms (Figures 4 and 5). At 14 dpi the maximum lesion length of $2.03 \mathrm{~cm}$ was recorded, induced by strain Dak1 on rice genotype FKR14. At 21 dpi the maximum mean lesion lengths $3.4 \mathrm{~cm}$ and $3.9 \mathrm{~cm}$ were induced by Dak1 on genotypes IRBB4 and FKR14, respectively. All the strains demonstrated increases of phytotoxicity effects on both rice genotypes comparing 14 and 21 dpi.

The comparison of phytotoxicity of the ethyl acetate fraction from culture filtrate to non-extracted culture filtrate at $21 \mathrm{dpi}$ revealed

\begin{tabular}{|l|l|l|l|l|l|}
\hline & SS & DF & MS & F & P \\
\hline Treatments & 1298.960 & 1 & 1298.960 & 420.467 & $0.000000^{\star * *}$ \\
\hline Strains & 157.310 & 3 & 52.437 & 16.974 & $0.000001^{\star * *}$ \\
\hline Rice Genotypes & 52.585 & 1 & 52.585 & 17.021 & $0.000246^{\star * *}$ \\
\hline Treatments x Strains & 251.885 & 3 & 83.962 & 27.178 & $0.000000^{\star * *}$ \\
\hline Treatments x Rice Genotypes & 14.257 & 1 & 14.257 & 4.615 & $0.039366^{\star *}$ \\
\hline Strains x Rice Genotypes & 121.773 & 3 & 40.591 & 13.139 & $0.000009^{\star * *}$ \\
\hline $\begin{array}{l}\text { Treatments x Strains x Rice } \\
\text { Genotypes }\end{array}$ & 74.693 & 3 & 24.898 & 8.059 & $0.000386^{* * *}$ \\
\hline Error & 98.859 & 32 & 3.089 & & \\
\hline
\end{tabular}

Note:*** p-value highly significant at $0.01 ;{ }^{* *} p$-value significant at 0.05 ; SC: Sum of Square; DF: Degree of freedom, MS: Mean square; F: F of Fisher; p: probability

Table 3: Statistics of comparison of Xanthmonas oryzae pv. oryzae culture filtrate effects to culture filtrate treated with proteinase $\mathrm{K}$ at $21 \mathrm{dpi}$.

\begin{tabular}{|l|l|l|l|l|l|}
\hline & SS & DF & MS & F & P \\
\hline Treatment & 1724.74 & 1 & 1724.74 & 555.366 & $0.000000^{\star \star *}$ \\
\hline Strains & 139.209 & 3 & 46.403 & 14.942 & $0.000011^{* \star *}$ \\
\hline Rice Genotypes & 9.825 & 1 & 9.825 & 3.164 & 0.087962 \\
\hline Treatment x Strains & 125.881 & 3 & 41.96 & 13.511 & $0.000023^{\star \star *}$ \\
\hline Treatment x Rice Genotypes & 0.001 & 1 & 0.001 & 0 & 0.988431 \\
\hline Strains x Rice Genotypes & 51.367 & 3 & 17.122 & 5.513 & $0.005024^{\star \star *}$ \\
\hline $\begin{array}{l}\text { Treatment x Strains x Rice } \\
\text { Genotypes }\end{array}$ & 26.518 & 3 & 8.839 & 2.846 & 0.058835 \\
\hline Error & 74.534 & 24 & 3.106 & & \\
\hline
\end{tabular}

Note: ${ }^{* * *}$ p-value highly significant at 0.01 ; SC: Sum of Square; DF: Degree of freedom, MS: Mean square; F: F of Fisher; p: probability

Table 4: Comparison of effects of Xanthmonas oryzae pv. oryzae culture filtrate to culture filtrate extracted with ethyl acetate at $21 \mathrm{dpi}$. 


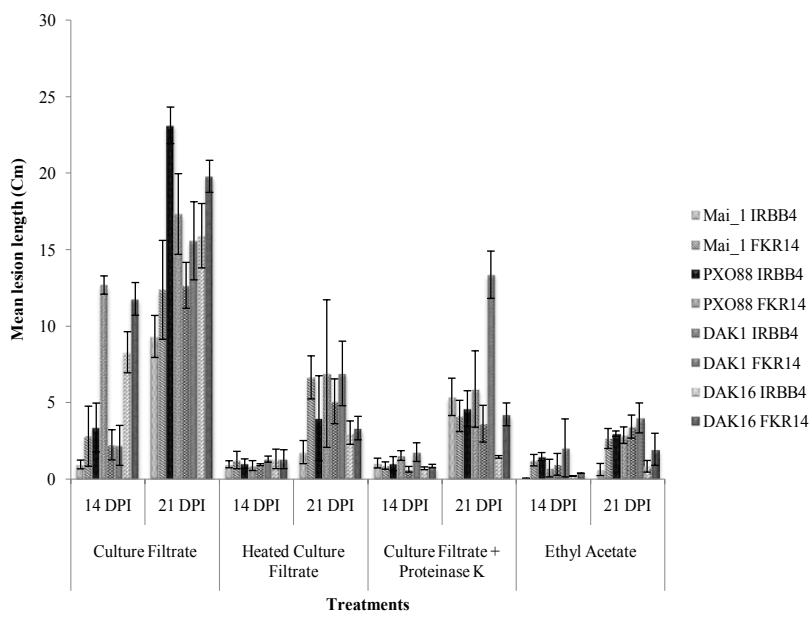

Figure 6: Comparison of $X$. oryzaepv. oryzaestrains Mai1, PXO88, Dak1 and Dak16 culture filtrate, heated culture filtrate, culture filtrate treated with proteinase $\mathrm{K}$ and culture filtrate extracted with ethyl acetate effects on genotypes IRBB4 and FKR14, measured in lesions length [cm] at 14 and $21 \mathrm{dpi}$

significantly lower lesion lengths induced by ethyl acetate extract compared to culture filtrate effects (Table 4). Significant differences were found between strains, and also the interaction between strains and rice genotypes was significant $(\mathrm{p}=0.005)$. Treatments and rice genotypes interaction revealed not significant at $21 \mathrm{dpi}$.

\section{Discussion}

\section{Strain virulence}

The virulence analysis result showed that Asian strain PXO88 is highly virulent compared to African strains used in this study. Also, within African strains, phenotypic differences were found. It has been reported that African Xoo strains are genetically distant from Asian strains [21]. Further studies with a higher number of strains are recommended. Two groups have been reported within the West African Xoo population [22]. The variability in the Xoo population is a consequence of the development of resistance durability of the bacterial races in time and space [23-25].

Near isogenic lines (NILs) with specific resistance genes have been identified and among them, lines with a single resistance gene are widely used to characterize virulence and differentiate pathogenic races of Xoo. Classification of the pathogenic race of Xoo is based on the interaction between its avr gene and rice $X a$ gene [23,26-28]. In this study, we used IRBB4 line carrying Xa4 gene and the susceptible genotype FKR14. The phenotypic reactions of the bacteria strains and rice line IRBB4 were similar to the reaction observed on FKR14 except with strain Mai1. IRBB4 line shows susceptibility to Xoo strains from Iran [28], while in China; it is susceptible to $50 \%$ of Chinese Xoo strains [29]. In earlier 1970, the Xoo populations were dominated by those strains that could not infect rice lines with $\mathrm{Xa} 4$ gene [30], while the newly developed rice lines with $\mathrm{Xa} 4$ gene are nowadays susceptible to several strains [31]. Strain Mail revealed non-virulent on IRBB4, confirming previous study on African Xoo strains, which reported that African Xoo race 3 is not virulent on IRBB4 [21].

\section{Phytotoxicity effects from Xoo culture filtrate and treated culture filtrate on rice}

X. oryzae pv. oryzae strains (Mai1, PXO88, Dak1 and Dak16) culture filtrate, heated culture filtrate, culture filtrate treated with proteinase $\mathrm{K}$ and ethyl acetate extract were used to study their phytotoxicity effect on rice genotypes IRBB4 and FKR14. Culture filtrate had the highest phytotoxicity effect against rice genotypes compared to heated culture filtrate, culture filtrate treated with proteinase $\mathrm{K}$ and ethyl acetate extract. The least square mean (LSM) lesion length evoked by bacteria culture was $18.1 \mathrm{~cm}$, while with culture filtrate, heated culture filtrate, culture filtrate treated with proteinase $\mathrm{K}$ and ethyl acetate extract the lesion lengths LSM were 15.8, 4.7, 5.4 and $2.4 \mathrm{~cm}$, respectively (data not shown). This result revealed, that the phytotoxicity of culture filtrate is similar to the phytotoxicity produced by bacteria, where strain Dak16 demonstrated no significant difference between bacteria culture lesion $(15.9 \mathrm{~cm}$ and $21.4 \mathrm{~cm})$ and its culture filtrate phytotoxicity lesion (15.9 $\mathrm{cm}$ and $19.8 \mathrm{~cm}$ ) on rice genotypes IRBB4 and FKR14, respectively. The bacteria cultures showed variations in their reactions on rice genotypes, and the same variations were also found by inoculation with culture filtrate, revealing that phytoxicity on rice is possibly produced by Xoo virulence factors. Significant differences were found between bacteria culture and culture filtrate effects, with higher effects of bacteria culture than culture filtrate with strains Dak16, strains PXO88 and Dak140, with phytotoxicity of culture filtrate $(9.3 \mathrm{~cm})$ being higher than bacteria effect $(3.6 \mathrm{~cm})$ of strain Mail on rice genotype IRBB4.

While the bacteria culture filtrate induced a phytotoxicity effect with a maximum lesion length of up to $23 \mathrm{~cm}$, the heated culture filtrate induced $6.9 \mathrm{~cm}$ of mean length. Thus, the heating treatment caused a reduction of the phytotoxicity of the culture filtrate. This results, possibly indicating that the culture filtrate effect was related to lipopolysaccharides, xylanase, polygalacturonase that Xoo produced and are reported as typical bacteria virulence factors [6,32] - and which were inactivated or killed by heating. Generally, enzymes are inactivated at higher temperature. The optimum temperature for the activity of Bacillus subtilis xylanase is $55^{\circ} \mathrm{C}$, and $0-45^{\circ} \mathrm{C}$ for Aspergillus flavus polygalacturonase, and while at $80^{\circ} \mathrm{C} 25 \%$ activities remained $[33,34]$. Therefore, the low phytotoxicity observed with heated culture filtrate in this study with $80^{\circ} \mathrm{C}$ of heating temperature should have affected the enzymes' activity in the culture filtrate.

The culture filtrate treated with proteinase $\mathrm{K}$ revealed generally lower phytotoxicity effect compared to other treatments, though the lesions were slightly larger than with heated culture filtrate. This finding supported the hypothesis that Xoo culture filtrate phytotoxicity is due to enzymes' activities or to proteins. Higher effect of culture filtrate treated with proteinase $\mathrm{k}$ could be due to presence of proteinaceous in the culture fitrate which perhaps inhibits the activity of related enzymes. Proteins including adhesion proteins are secreted via the Two Partner Secretion System (TPS) and contribute to virulence by bacteria attachment to the host surface $[7,35]$. Xoo produces proteins that are required for virulence, and the inactivation of proteins in heat-treated Xoo culture filtrate would be related to the low observed phytotoxicity effect on the rice genotypes. Chatterjee and Sonti [36] reported that Xoo protein phytase A (PhytA) is required for virulence. Xoo strain Dak1 showed $13.3 \mathrm{~cm}$ lesion length with culture filtrate treated with proteinase $\mathrm{K}$ on rice genotype FKR14, while other strains showed less effect. This result is in contrast to the fact that Xoo secreted proteins are required for virulence. Plant-pathogen interactions are related to the plant defense response from the initial recognition event to defense or susceptibility reactions. Generally, plant elicitors in response to a stress can be race specific. This could explain the fact, that Xoo strain Dak1 culture filtrate treated with proteinase $\mathrm{K}$ overcame the rice genotype FKR14 defense barriers in absence of proteins and induced a similar phytotoxicity effect compared to culture filtrate. 
The ethyl acetate extract showed the lowest effect on rice genotypes compared to other treatment revealing that the ethyl acetate extract did not contain an active virulence factor inducing phytotoxicity. Therefore, we suggest, that Xoo does not produce low molecularweight secondary metabolites (toxins) significantly involved in the bacterial virulence against the rice plant. The only phytotoxicity effect observed on rice leaves after treatment was leaf discoloration. Previous study (Shao and Wang, 1997) on Xoo culture filtrate revealed that Xoo culture filtrate contains some elicitors, which induced a toxicity effect on rice, and induced rapid necrosis on tobacco leaves. Our result also corroborates the data from Kong et al. [18] who found after extracting from bacteria culture with ethyl acetate, that Xoo toxins induced leaf discoloration and cell death on rice. A necrotic lesion as observed in our study has been reported from many bacteria species producing phytotoxic compounds. A phytotoxic compound of Pseudomonas syringae pv. sesame induced necrotic symptoms [37], which were similar to the phytotoxicity of mangotoxin from $P$. syringae pv. syringae strain UMAF0158 on mango tree [38]. Several toxins similar to lipodepsipeptide produced by strains of $P$. syringae pv. syringae were reported [39-41] such as syringomycins and syringopeptins which induced necrotic symptoms on plants $[42,43]$. Ethyl acetate extract treatments induce also chlorosis and necrosis on both rice genotypes IRBB4 and FKR14. The phytotoxin coronatine and antimetabolite toxins induced chlorosis and an increase in disease symptoms, respectively, and are considered as virulence factors in $P$. syringae [4447], while Xoo ethyl acetate extract, did not increase disease symptoms, and therefore it is not, that the ethyl acetate extract contains virulence factor with phytotoxic activity.

Differences were seen between treatments, strains and rice genotypes. The culture filtrate effect was highest, and a considerable decrease of phytotoxicity was observed with the other treatments. We do not rule out that Xoo might produce a compound to induce phytotoxicity on rice leaves, but this compound may only to a minor extent contribute to the bacterial virulence. On the contrary, Noda et al. [48] identified seven toxic substances in ethyl acetate soluble acidic material: 3-methylthioproprionic acid, trans-3-methylthioacrylic acid, phenylacetic acid, isovaleric acid, tiglic acid, succinic acid and fumaric acid, isolated from Xoo culture suspension. His culture suspension induced necrosis and chlorosis on rice leaves at higher concentration $(2000 \mu \mathrm{g} / \mathrm{ml})$. We suppose that the contradictory results are due to the fact that Noda et al. [48] extracted the toxic substances from culture suspensions which contain bacteria, but we extracted from culture filtrate where bacteria were removed. Thus, when we also treated bacteria culture suspension with heat and proteinase $\mathrm{K}$ instead of treating the culture filtrate as in our general trials, we also found a higher phytotoxicity effect than with culture filtrate treated in the same way. Therefore, we believe that the Xoo virulence factors remain in association with the bacteria. Furthermore, secreted proteins including adhesins have been reported to be involved in the bacterial virulence, as well as the diffusible factor signal (DFS) synthase, which belongs to the enoyl-co-A-hydratase family and plays an important role in attachment, biofilm formation and virulence of Xoo [49].

The difference between strains could be related to the strains' virulence and/or to the genetic or geographic distance between strains. Gonzalez et al. [21] found that African strains are genetically distant from Asian strains, while Onasanya et al. [22] found two groups within West African Xoo. The differences observed between rice genotypes which showed highest effect against rice genotype FKR14 than IRBB4 corroborate the study of Shao and Wang [19]. The biochemical approach for virulence factors identification in Xoo revealed no small metabolites playing a major role in Xoo virulence.

\section{Conclusion}

Biochemical assays for virulence factor identification in cultures, culture filtrate, heated culture filtrate, culture filtrate treated with proteinase $\mathrm{K}$ and in the ethyl acetate extracted fraction of Xoo strains Mai1, PXO88, Dak1 and Dak16 were carried out on rice genotypes IRBB4 and FKR14. Culture filtrate induced phytotoxicity effects on both rice genotypes with lesion lengths comparable to lesion lengths induced by the bacteria culture. A considerable reduction in phytotoxicity effects was observed with proteinase $\mathrm{K}$ treated culture filtrate, after heating culture filtrate and with ethyl acetate extract, in reducing order. First symptoms were visible after inoculation of Xoo cultures and ethyl acetate fraction at $3 \mathrm{dpi}$, with culture filtrate at one week and with heated culture filtrate and culture filtrate treated with proteinase $\mathrm{K}$ at $10 \mathrm{dpi}$. Statistical analyses confirmed that the phytotoxicity effects were significantly influenced by strains and by rice genotypes, and also the interactions treatments strains, strains rice genotypes and treatments strains rice genotypes were significant. We suggest, additionally to LPS, polygalacturonase and Xylanase, Xoo produces a proteinaceous virulence factor. Further factors possibly attached to the bacterial cells were not the target of the present study.

\section{Acknowledgment}

We thank the German Federal Ministry for Economic Development Cooperation (BMZ) for financing these studies in the framework of the mitigating the impact of climate change on rice diseases resistance in East Africa (MICCORDEA) project of Africa Rice Centre. We also thank Dr. Negussie Zenna for his help in samples collection in Tanzania.

\section{References}

1. Mew TW (1987) Current status and future prospects of research on bacteria blight of rice. Annu. Rev. Phytopathol. 25: 359-382.

2. Mew TW, Reyes RC, Vera Cruz CM (1989) Screening for bacterial blight resistance in rice. In Methods in Phytobacteriology 338-341 (Eds.): Z. Klement K. Rudolph and D.C. Sands. Akademiai, Kiado, Budapest.

3. Robert KW, Pamela SG (1992) Foliar diseases: bacterial blight. Compendium of Rice Disease 1992; University of California, Davis. pp. 10-11.

4. Ray SK, Rajeshwari R, Sonti RV (2000) Mutants of Xanthomonas oryzae pv. oryzae deficient in general secretory pathway are virulence deficient and unable to secrete xylanase. Mol Plant Microbe Interact 13: 394-401.

5. Jha G, Rajeshwari R, Sonti RV (2007) Functional interplay between two Xanthomonas oryzae pv,. oryzae secretion systems in modulating virulence on rice. Mol Plant Microbe Interact 20: 31-40.

6. Wang CL, Xu A, Gao Y, Fan YL, Liang YT, et al. (2008) Generation and characterization of Tn5-tagged Xanthomonas oryzae pv. oryzae mutants that overcome Xa23 -mediated resistance to bacterial blight of rice. Eur J Plant Pathol. 123: 343-351.

7. Ray SK, Rajeshwari R, Sharma Y, Sonti RV (2002) A high-molecular-weight outer membrane protein of Xanthomonas oryzae pv. oryzae exhibits similarity to non-fimbrial adhesions of animal pathogenic bacteria and is required for optimal virulence. Mol Microbiol 46: 637-647.

8. Shen Y, Ronald P (2002) Molecular determinants of disease and resistance in interactions of Xanthomonas oryzae pv. oryzae and rice. Microbes Infect 4 1361-1367.

9. Das A, Rangaraj N, Sonti RV (2009) Multiple adhesin-like functions of Xanthomonas oryzae pv. oryzae are involved in promoting leaf attachment entry, and virulence on rice. Mol Plant Microbe Interact 22: 73-85.

10. Pieretti I, Royer M, Barbe V, Carrere S, Koebnik R, et al. (2009) The complete genome sequence of Xanthomonas albilineans provides new insights into the reductive genome evolution of the xylem-limited Xanthomonadaceae. BMC Genomics 10: 616.

11. Van Sluys MA, Monteiro-Vitorello CB, Camargo LE, Menck CF, Da Silva AC 
et al. (2002) Comparative genomic analysis of plant-associated bacteria. Annu Rev Phytopathol 40: 169-189.

12. Ryan RP, Vorhölter FJ, Potnis N, Jones JB, Van Sluys MA, et al. (2011) Pathogenomics of Xanthomonas: understanding bacterium-plant interactions. Nat Rev Microbiol 9: 344-355

13. Erdman JG, Marlett EM, Hanson WE (1956) Survival of Amino Acids in Marine Sediments. Science 124: 1026

14. Sugawara M, Haramaki R, Nonaka S, Ezura H, Okazaki S, et al. (2007) Rhizobitoxine production in Agrobacterium tumefaciens $\mathrm{C} 58$ by Bradyrhizobium elkanii rtxACDEFG genes. FEMS Microbiol Lett 269: 29-35.

15. Oresnik IJ, Twelker S, Hynes MF (1999) Cloning and characterization of a Rhizobium leguminosarum gene encoding a bacteriocin with similarities to RTX toxins. Appl Environ Microbiol 65: 2833-2840.

16. Simpson AJ, Reinach FC, Arruda P, Abreu FA, Acencio M, et al. (2000) The genome sequence of the plant pathogen Xylella fastidiosa. The Xylella fastidiosa Consortium of the Organization for Nucleotide Sequencing and Analysis. Nature 406: 151-159.

17. Lee BM, Park YJ, Park DS, Kang HW, Kim JG, et al. (2005) The genome sequence of Xanthomonas oryzae pathovar oryzae KACC10331, the bacterial blight pathogen of rice. Nucleic Acids Res 33: 577-586.

18. Kong F, Xu Z, Chunhong M, Wei J (1998) On the specific toxicity of toxin produced by Xanthomonas oryzae pv. oryzae to cytoplasmicmale sterile rice zhenshan 97a. Acta Phytopathol Sinica 28: 113-116.

19. Shao M, Wang JS (1997) Extraction, bioassay and composition analysis of the toxin from Xanthomonas oryzae pv. oryzae. Acta Phytopathol Sinica 27: $315-320$

20. Kauffman HE, Reddy APK, Hsieh SPY, Merca SD (1973) An improved technique for evaluating resistance of rice varieties to Xanthomonas oryzae. Plant Dis Rep 57: 537-541.

21. Gonzalez C, Szurek B, Manceau C, Mathieu T, Séré Y, et al. (2007) Molecular and pathotypic characterization of new Xanthomonas oryzae strains from West Africa. Mol Plant Microbe Interact 20: 534-546.

22. Onasanya A, Ekperigin MM, Nwilene FE, Sere Y, Onasanya RO (2009) Two pathotypes of Xanthomonas oryzae pv. oryzae virulence identified in West Africa. Cur Res Bact 2: 22-35.

23. Adhikari TB, Basnyat RC, Mew TW (1999) Virulence of Xanthomonas oryzae pv. oryzae on rice lines containing single resistance genes and gene combinations. Plant Dis 83: $46-50$

24. Nodal T, Li C, Li J, Ochiai H, Ise K, Kaku H (2001) Pathogenic diversity of Xanthomonas oryzae pv. oryzae strains from Yunnan province, China. Jpn Agric Res Q 35: 97-103.

25. Jagjeet SL, Yogesh V, Mandeep SH, Ravinder KG, Tajinder SB et al. (2011) Genotypic and pathotypic diversity of Xanthomonas oryzae pv. oryzae, the cause of Bacterial blight of rice in Punjab State of India. J of Phytopathol 159 479-487.

26. Mew TW, Alvarez AM, Leach JE, Swings J (1993) Focus on bacterial blight of rice. Plant Disease 77: 5-12.

27. Jeung JU, Heu SG, Shin MS, Vera Cruz CM, Jena KK (2006) Dynamics of Xanthomonas oryzae pv. oryzae Populations in Korea and Their Relationship to Known Bacterial Blight Resistance Genes. Phytopathology 96: 867-875

28. Khoshkdaman M, Ebadi AA, Kahrizi D (2012) Evaluation of pathogencity and race classification of Xanthomonas oryzae pv. oryzae in Guilan province-Iran. Agr Sci 3: 557-561.

29. Gang L, Cong-Feng S, Xiao-Mia P, Yue Y, Jin-Sheng W (2009) Analysis of pathotypic and genotypic diversity of Xanthomonas oryzae pv. oryzae in China. J of Phytopathology 157: 208-218.

30. Mew TW, Vera Cruz CM, Medalla ES (1992) Changes in race frequencies of Xanthomonas oryzae pv. oryzae in response to the planting of rice cultivars. Plant Dis 76: 1029-32.

31. Vera Cruz CM, Bai J, Ona I, Leung H, Nelson RJ, et al. (2000) Predicting durability of a disease resistance gene based on an assessment of the fitness loss and epidemiological consequences of avirulence gene mutation. Proc Nat Acad Sci U S A 97: 13500-13505

32. Rajeshwari R, Jha G, Sonti RV (2005) Role of an in planta-expressed xylanase of Xanthomonas oryzae pv. oryzae in promoting virulence on rice. Mol Plant Microbe Interact 18: 830-837.

33. Sanghi A, Garg N, Gupta VK, Mittal A, Kuhad RC (2010) One-step purification and characterization of cellulase-free xylanase produced by alkalophilic Bacillus subtilis ash. Braz J Microbiol 41: 467-476.

34. Gewali MB, Maharjan J, Thapa S, Shrestha JK (2007) Studies on polygalacturonase from Aspergllus flavus. Sci World 5: 19-22.

35. Tseng TT, Tyler BM, Setubal JC (2009) Protein secretion systems in bacterialhost associations, and their description in the Gene Ontology. BMC Microbiol 9 Suppl 1: S2.

36. Chatterjee S, Sonti RV (2002) rpfF mutants of Xanthomonas oryzae pv. oryzae are deficient for virulence and growth under low iron conditions. Mol Plant Microbe Interact 15: 463-471.

37. Firdous SS, Asghar R, Haque MI, Afzal SN, Murtaza G et al. (2010) Isolation, purification, characterization and identification of virulence factors of Pseudomonas syringae pv. sesame and Xanthomonas campestris pv. sesami. Pak J Bot 42: 4191-4198.

38. Arrebola E, Cazorla FM, Duran VE, Rivera E, et al (2003) Mangotoxin: a nove antimetabolie toxin produced by Pseudomonas syringae inhibiting ornithine/ arginine biosynthesis. Physiol Mol Plant Pathol 63: 117-127.

39. Gross DC, DeVay JE (1977) Production and purification of syringomycin, a phytotoxin produced by Pseudomonas syringae. Physiol Plant Pathol 11: 1328.

40. Gross DC, Hutchinson ML, Scholz BK, Zhang JH (1997) Genetic analysis of the role of toxin production by Pseudomonas syringae pv. syringaein plant pathogenesis. In: Pseudomonas syringae pathovars and Related Pathogens pp.163-169.

41. Ballio A, Barra D, Bossa F, Collina A, Grgurina I, et al. (1991) Syringopeptins new phytotoxic lipodepsipeptides of Pseudomonas syringae pv. syringae. FEBS Lett 291: 109-112.

42. Sinden SL, DeVay JE, Backman PA (1971) Properties of syringomycin, a wide spectrum antibiotic and phytotoxin produced by Pseudomonas syringae and its role in the bacterial canker disease of peach trees. Physiol Plant Pathol 1 199-213.

43. lacobellis NS, Lavermicocca P, Grgurina I, Simmaco M, Ballio A (1992) Phytotoxic properties of Pseudomonas syringae pv. Syringae toxins. Physiol Mol Plant Pathol 40: 107-116

44. Bender CL, Young SA, Mitchell RE (1991) Conservation of Plasmid DNA Sequences in Coronatine-Producing Pathovars of Pseudomonas syringae. Appl Environ Microbiol 57: 993-999.

45. Bender CL, Alarcón-Chaidez F, Gross DC (1999) Pseudomonas syringae phytotoxins: mode of action, regulation, and biosynthesis by peptide and polyketide synthetases. Microbiol Mol Biol Rev 63: 266-292.

46. Arrebola E, Cazorla FM, Codina JC, Gutiérrez-Barranquero JA, Pérez-García A, et al. (2009) Contribution of mangotoxin to the virulence and epiphytic fitness of Pseudomonas syringae pv. syringae. Int Microbiol 12: 87-95

47. Carrión VJ, Arrebola E, Cazorla FM, Murillo J, de Vicente A (2012) The mbo operon is specific and essential for biosynthesis of mangotoxin in Pseudomonas syringae. PLoS One 7: e36709.

48. Noda T, Sato Z, Kobayashi H, Iwasaki S, Okuda S (1980) Isolation and structural elucidation of phytotoxic substances produced by Xanthomonas campestris pv. oryzae (Ishiyama) Dye. Ann Phytpath Soc Japan 46: 663-666.

49. Rai R, Ranjan M, Pradhan BB, Chatterjee S (2012) Atypical regulation of virulence-associated functions by a diffusible signal factor in Xanthomonas oryzae pv. oryzae. Mol Plant Microbe Interact 25: 789-801. 